\title{
Bacterial Isolates in Asio Otus and Strix Aluco Bids of Prey
}

\author{
Nicodim Iosif FIŢ*, Cosmin MUREȘAN, Flore CHIRILĂ, Sorin RĂPUNTEAN, Adriana CRISTE and George \\ NADĂȘ \\ University of Agricultural Sciences and Veterinary Medicine Cluj-Napoca, Faculty of Veterinary Medicine, \\ 3-5 Mănăștur Street, 400372, Romania \\ *Corresponding author: nfit@usamvcluj.ro
}

Bulletin UASVM Veterinary Medicine 72(2) / 2015,

Print ISSN 1843-5270; Electronic ISSN 1843-5378

DOI:10.15835/buasvmcn-vm: 11743

\begin{abstract}
Birds of prey such as long-eared owl (Asio otus) and little owl (Strix aluco) are part of a special category of birds because of their direct contact with many species of wild rodents, thus posing as vectors for transmission of microbial agents in some territories. The study describes the types of bacteria isolated from long-eared and little owls as well as the antibiotic susceptibility of isolates. The study was conducted on Asio otus and Strix aluco adults representing casuistry from the Clinical Hospital of the Faculty ofVeterinary Medicine Cluj-Napoca, consulted between December 2014-April 2015 and from the Leisure Park „Moara de Vânt” Ciurila village, Salicea, Cluj County.

Sampling was performed from the cloaca, oral, axillary region and skin wounds. The identification of bacteria was carried out by bacteriological examinations using phenotypic techniques and thereafter isolates were tested for susceptibility by disc diffusion method. Tests showed an increased amount of bacterial specimens in the mouth and cloaca. From the skin, a small number of bacteria were isolated, while from skin wounds even scarcer isolates were identified.

It wasobserved that in most cases the Escherichia, Bacillus, and Staphylococcus genus were the predominant isolates in both oral and cloacal cavity.The sensitivity assays showed that most tested strains were susceptible to Enrofloxacin, and Florfenicol. Among all the tested antibiotics, amoxicillin had the lowest susceptibility.. This study showed that major and conditioning pathogenic bacteria were predominantly isolated from Strix aluco and Asio otus`s mucous membranes. It has also been pointed out that isolates pose great sensitivity to currently used antibiotics in birds.
\end{abstract}

Keywords: antibiotic resistance, bacterial flora of cloaca, oral cavity, Asio otus, Strix aluco

\section{INTRODUCTION}

Wild birds are involved in the dispersal of microorganisms as biological carriers or as vectors. Birds of pray can alsobe infected by hematophagous ectoparasites. Many species of pathogenic bacteria specific to vertebrates, are also present in healthy birds, which can play an important role in the ecology and spread of microorganisms (Kiskova et al. 2012). The dispersion of bacteria is dependent on the presence of both biotic and abiotic factors. The exact status of specific microorganisms in captive wild birds and their way of dispersing is not completely described (Soler et al., 2009).

Lately, many cases have been reported were wild birds are involved in transmission of human bacterial infections (Tsiodras et al., 2008). At the same time, birds are great indicators of health in a given habitat (Abulreesh et al., 2007). Most likely birds of prey become carriers after eating mammals, wild birds and also infected cadavers of sick animals. It is also known that raptors are susceptible to infectious diseases only when they 
become immunosuppressed due to various factors, particularly environmental, otherwise they are asymptomatic carriers (Tsiodras et al., 2008).

Birds of prey groups are divided into day and night raptors. Night raptors group found in Transylvania are represented by Order Strigiformes, which has a single-family, the Strigidae (Simonescu 1983, Dieter, 2010).

Since ancient times birds of prey were trained for hunting, in the context of the modern world, the relationship between people and wildlife, including birds, is stronger. Considering that lately contact between humans and birds is imminent due to restricted habitat, knowledge of specific bacterial flora in raptors is heavely important because of the zoonotic risk in man (Thomas et al. 2008).

The aim of this study was to evaluate the microbial load and antibiotic resistance of birds of prey such as Strix aluco and Asio otus, in the North - West of Transylvania. This study finds its importance due to the pathogenic potential of normal flora to manifest only in certain circumstances, especially when normal mechanisms of the body's defenses are overcomed.

\section{MATERIALS AND METHODS}

Biological material: The experiment was conducted during December 2014-April 2015 on samples collected from the Clinical Hospital of the Faculty of Veterinary Medicine Cluj-Napoca case load and from the Leisure Park „Moara de Vânt” Ciurila village, Salicea, Cluj County. The studied groups were represented by two night raptors species. A total of 22 animals were included in the study out of which 10 were long-eared owls (Asio otus) and 12 tawny owls (Strix aluco). From these birds swabs were collected from the oral cavity, cloaca, the skin of armpits and in some birds from wounded skin.

Identification of bacteria: Standard microbiological assays were used in order to isolate and test bacterial strains. Isolates were identified by using phenotypic techniques such as morphological, cultural characters and biochemical assays as described by Markey et al. (2013). For this purpose the samples were initially inoculated on Blood agar medium (bioMérieux), MacConkey agar (Neogen) and Cetrimide agar (HiMedia Laboratories). Subsequently colonies were examined and tested on biochemical tests, using 20 to 50 galleries API assays - bioMérieux (API 20 Strep, API CORYNE, API NH, API STAPH API 20E, API 20NE API 50CHB). The results were runed by Apiweb software program (bioMérieux).

Antibiotic susceptibility: for susceptibility tests five heavy grown potentially pathogenic isolates (Staphylococcus spp., Bacillus cereus, Escherichia coli, Pseudomonas spp. and Proteus mirabilis)were evaluated.From these isolates, 5 strains each were tested by disc diffusion method according to CLSI Vet 01 - A4 (2013) by using the following seven antibiotics produced by Bioanalyse: Amoxicillin (AX-30), Tetracycline (TE-30), Enrofloxacin (ENR10) Florfenicol (FFC-30) Lincomycin (L-10), Cephalexin (CL-30) and Doxycycline (DO-30).

\section{RESULTS AND DISCUSSIONS}

The results showed that out of 34 samples taken from Asio otus, 14 different bacterial species were isolated (Table 1). The highest number of isolated species was found in the cloaca (i.e. 30 isolates), whilst lowest numbers were isolatede from wounds (i.e. 9 isolates). It was noted that in the oral cavity the bacterial diversity was highest by isolating bacteria from 9 differentspecies, predominantly Gram positive aerobic species such as Staph. spp. isolated in $60 \%$ of tested samples. From the cloaca 6 different bacterial strains were isolated, out of which $90 \%$ of bacterias were E. coli . From skin, all 6 types of bacteria were isolated, out of which $60 \%$ were spore forming Bacillus cereus specimens. From skin wounds, 4 different bacteria types were identified, with Bacillus cereus still as the predominant species.

In Strix aluco, of the 42 processed samples 15 types of bacteria specimens were identified (Table 2 ). The number of bacterial variety isolated from the oral cavity was equal to the number of species isolated from the cloaca. Similar to the previous species, from the mouth, Gram-positive isolates were the main type of bacteria encountered (Streptococcus spp. 41.6\%) whilst for cloaca, Gram negative bacteria like $E$. coli were identified in $66.6 \%$ of tested samples. The number of bacterial types from skin and skin wounds was the same (6 species) but the species difered. Only in Strix aluco, Leifsonia aquatica was identified in the cloaca and in the wounds (i.e. 4 isolates).

The overall analysis of bacterial species in the two species of raptors from this study, points out that they have a bacterial flora similar in number 
Table 1 Overall percentage of different types of bacteria isolated from different types of samples collected from birds of prey - Asio otus.

\begin{tabular}{|c|c|c|c|c|c|}
\hline Type of bacteria & $\begin{array}{c}\text { Oral swab } \\
(n=10)\end{array}$ & $\begin{array}{c}\text { Cloacal swab } \\
(\mathrm{n}=10)\end{array}$ & $\begin{array}{c}\text { Skin swab } \\
(n=10)\end{array}$ & $\begin{array}{c}\text { Wound swab } \\
(\mathrm{n}=4)\end{array}$ & $\begin{array}{c}\text { Total } \\
(\mathrm{n}=34)\end{array}$ \\
\hline Streptococcus spp. & $2(20)$ & & & & $2(5.8)$ \\
\hline Staphylococcus spp. & $6(60)$ & & $2(20)$ & & $8(23.5)$ \\
\hline Micrococcus spp. & $1(10)$ & & $2(20)$ & & $3(8.8)$ \\
\hline Corynebacterium spp. & $2(20)$ & & & $2(20)$ & $4(11.7)$ \\
\hline Bacillus cereus & $5(50)$ & $6(60)$ & $6(60)$ & $3(30)$ & $20(58.8)$ \\
\hline Bacillus megaterium & & & $1(10)$ & & $1(2.9)$ \\
\hline Escherichia coli & $2(20)$ & $9(90)$ & $4(40)$ & $2(20)$ & $17(50)$ \\
\hline Salmonella spp. & & $3(30)$ & & & $3(8.8)$ \\
\hline Enterococcus faecalis & $1(10)$ & $2(20)$ & & & $3(8.8)$ \\
\hline Klebsiella spp. & $2(20)$ & & & & $2(5.8)$ \\
\hline Proteus mirabilis & & $5(50)$ & $4(40)$ & & $9(26.4)$ \\
\hline Fusobacterium spp. & $2(20)$ & & & & $2(5.8)$ \\
\hline Pseudomonas spp. & & $5(50)$ & & & $5(14.7)$ \\
\hline Vibrio spp. & & & & $2(20)$ & $2(5.8)$ \\
\hline Total & $23(67.64)$ & $30(88.23)$ & $19(55.88)$ & $9(26.47)$ & \\
\hline
\end{tabular}

Table 2 Overall percentage of different types of bacteria isolated from different types of samples collected from birds of prey - Strix aluco.

\begin{tabular}{|c|c|c|c|c|c|}
\hline Type of bacteria & $\begin{array}{c}\text { Oral swab } \\
(\mathrm{n}=12)\end{array}$ & $\begin{array}{c}\text { Cloacal swab } \\
(\mathrm{n}=12)\end{array}$ & $\begin{array}{c}\text { Skin swab } \\
(\mathrm{n}=12)\end{array}$ & $\begin{array}{c}\text { Wound swab } \\
(\mathrm{n}=6)\end{array}$ & $\begin{array}{c}\text { Total } \\
(\mathrm{n}=42)\end{array}$ \\
\hline Streptococcus spp. & $5(41.6)$ & & & & $5(11.9)$ \\
\hline Staphylococcus spp. & $4(33.3)$ & & $5(41.6)$ & & $9(21.4)$ \\
\hline Micrococcus spp. & $3(25)$ & $1(8.3)$ & $4(33.3)$ & & $8(19)$ \\
\hline Corynebacterium spp. & $3(25)$ & & & $1(8.3)$ & $4(9.5)$ \\
\hline Bacillus cereus & $4(33.3)$ & $4(33.3)$ & $6(50)$ & $2(16.6)$ & $16(38.1)$ \\
\hline Bacillus megaterium & & & $1(8.3)$ & & $1(2.3)$ \\
\hline Escherichia coli & $4(33.3)$ & $8(66.6)$ & $5(41.6)$ & $2(16.6)$ & $19(42.2)$ \\
\hline Salmonella spp. & & $4(33.3)$ & & & $4(9.5)$ \\
\hline Enterococcus faecalis & $2(16.6)$ & $6(50)$ & & & $8(19)$ \\
\hline Klebsiella spp. & $1(8.3)$ & $3(25)$ & & & $4(9.5)$ \\
\hline Proteus mirabilis & & $5(41.6)$ & & $3(25)$ & $8(19)$ \\
\hline Fusobacterium spp. & $2(16.6)$ & & & & $2(4.7)$ \\
\hline Pseudomonas spp & & $3(25)$ & & $2(16.6)$ & $5(11.9)$ \\
\hline Leifsonia aquatica & & $2(16.6)$ & & $2(16.6)$ & $4(9.5)$ \\
\hline Vibrio spp. & & & $1(8.3)$ & & $1(2.3)$ \\
\hline Total & $28(66.6)$ & $36(85.71)$ & $22(52.38)$ & $12(28.5)$ & \\
\hline
\end{tabular}

and diversity of species. It was also observed that different species are isolated from different body areas, major pathogenic potential bacterial species such as Salmonella were also isolated. Studies on wild birds shows that fecal microbial flora is represented by species like E. coli, Bacillus 
Tabel 3 The results of antibiotic susceptibility, as a percentage of the isolates in Asio otus

\begin{tabular}{|c|c|c|c|c|c|c|c|c|c|}
\hline \multirow[t]{2}{*}{ Type of bacteria } & \multirow{2}{*}{$\begin{array}{l}\text { Nr. of } \\
\text { tested } \\
\text { strains }\end{array}$} & \multirow{2}{*}{$\begin{array}{c}\text { Sensitive/ } \\
\text { intermediate/ } \\
\text { resistance }\end{array}$} & \multicolumn{7}{|c|}{$\begin{array}{l}\text { The percentage of sensitivity of } \\
\text { isolated strains to antibiotics }\end{array}$} \\
\hline & & & $\mathrm{AX}$ & $\mathrm{TE}$ & ENR & $\mathrm{FFC}$ & $\mathrm{L}$ & CL & DO \\
\hline \multirow{3}{*}{ Staphylococcus spp. } & \multirow{3}{*}{5} & $\mathrm{~S}$ & 60 & 100 & 80 & 100 & 80 & 60 & 80 \\
\hline & & $\mathrm{I}$ & 20 & 00 & 20 & 00 & 20 & 40 & 20 \\
\hline & & $\mathrm{R}$ & 20 & 00 & 00 & 00 & 00 & 00 & 00 \\
\hline \multirow{3}{*}{ Bacillus cereus } & \multirow{3}{*}{5} & $\mathrm{~S}$ & 40 & 80 & 80 & 100 & 60 & 40 & 80 \\
\hline & & I & 40 & 20 & 20 & 00 & 20 & 40 & 20 \\
\hline & & $\mathrm{R}$ & 20 & 00 & 00 & 00 & 20 & 20 & 00 \\
\hline \multirow{3}{*}{ Escherichia coli } & \multirow{3}{*}{5} & $S$ & 20 & 20 & 80 & 20 & 20 & 00 & 20 \\
\hline & & I & 40 & 60 & 20 & 80 & 80 & 80 & 40 \\
\hline & & $\mathrm{R}$ & 40 & 20 & 00 & 00 & 00 & 20 & 40 \\
\hline \multirow{3}{*}{ Proteus mirabilis } & \multirow{3}{*}{5} & $S$ & 00 & 40 & 60 & 80 & 20 & 20 & 20 \\
\hline & & I & 20 & 60 & 40 & 20 & 80 & 40 & 80 \\
\hline & & $\mathrm{R}$ & 80 & 20 & 00 & 00 & 00 & 40 & 00 \\
\hline \multirow{3}{*}{ Pseudomonas spp. } & \multirow{3}{*}{5} & $\mathrm{~S}$ & 00 & 20 & 60 & 80 & 40 & 40 & 20 \\
\hline & & $\mathrm{I}$ & 20 & 20 & 20 & 20 & 40 & 20 & 60 \\
\hline & & $\mathrm{R}$ & 80 & 60 & 20 & 00 & 20 & 40 & 20 \\
\hline
\end{tabular}

Amoxicillin AX-30, Tetracycline TE-30, Enrofloxacin ENR-10, Florfenicol FFC-30, Lincomycin L-10, Cephalexin CL-30, Doxycycline D0-30 (Bioanalyse); $\mathrm{S}=$ sensitive, $\mathrm{I}=$ intermediate, $\mathrm{R}=$ resistance

spp., Staph. spp., Streptococcus spp., Acinetobacter spp. and Agrobacterium radiobacter in Corvus frugilegus. (Vlahović et al. 2010; Sarker et al. 2012).

Antibiotic resistance tests performed on Asio otus revealed that Gram-positive strains had a higher sensitivity to antibiotics by observing large inhibition areas to tetracycline and florfenicol (100\%). Gram-negative species had also high sensitivity to enrofloxacin and florfenicol in proportion of $60-80 \%$. Strains of Pseudomonas spp. and Proteus mirabilis were the most resistant strains (Table 3).

Antibioresistance analysis tests performed on strains isolated from Strix aluco showed similar results as in the previous species, were Gram positive strains posed higher sensitivity compared to the Gram-negative strains. Tested bacteria showed the highest sensitivity to florfenicol (i.e. $100 \%$ of strains). Most resistant strains were observed in Pseudomonas spp. and less-resistant strains were observed in Staphylococcus spp. (Table 4). Similar studies conducted by Olinda et al. (2012) found multiple resistance paterns for Proteus species in two wild birds (Agapornis spp. and Spheniscus magellanicus). Smith et al. (2014) found higher levels of antibiotic resistance to $\beta$-lactamases in birds (Larus argentatus) and $87 \%$ for mammals (Cervus elaphus) $31 \%$ in E. coli strains. Radhouani et al. (2014) showed that E. coli and Enterococci strains play an important role in monitoring the nature emerging antibiotic resistance phenomenon.

Studies by Mora et al. (2014) on griffon vulture (Gyps fulvus) showed that E. coli strains has great heterogeneity, however, they were not involved in producing extended-spectrum beta-lactamases (ESBL) antibioticoresistance, though observing high resistance to ampicillin and clotrimazole.

Recent studies on Salmonella carriars in wild birds in Italy shows that $4.3 \%$ of examined samples are positive, with resistance to multiple classes of antibiotics. The resistance for tetracycline was also very increased (Velcea et al. 2013). We found increased resistance to amoxicillin and tetracycline, in our 2 raptor species study.

\section{CONCLUSIONS}

Strix Aluco and Asio otus research regarding bacterial florashows that isolate population vary greatly from mucous membranes, skin and skin wounds. In the oral mucosae, Gram positive bacteria such as Streptococcus spp., Staphylococcus spp., and Bacillus cereus predominate, whilst from 
Tabel 4 The results of antibiotic susceptibility, as a percentage of the isolates in Strix aluco

\begin{tabular}{|c|c|c|c|c|c|c|c|c|c|}
\hline \multirow[t]{2}{*}{ Type of bacteria } & \multirow{2}{*}{$\begin{array}{c}\text { Nr. of } \\
\text { tested } \\
\text { strains }\end{array}$} & \multirow{2}{*}{$\begin{array}{c}\text { Sensitive/ } \\
\text { intermediate/ } \\
\text { resistance }\end{array}$} & \multicolumn{7}{|c|}{$\begin{array}{l}\text { The percentage of sensitivity of } \\
\text { isolated strains to antibiotics }\end{array}$} \\
\hline & & & $\mathrm{AX}$ & $\mathrm{TE}$ & ENR & FFC & $\mathrm{L}$ & $\mathrm{CL}$ & DO \\
\hline \multirow{3}{*}{ Staphylococcus spp. } & \multirow{3}{*}{5} & $\mathrm{~S}$ & 40 & 80 & 80 & 100 & 80 & 80 & 80 \\
\hline & & $\mathrm{I}$ & 40 & 20 & 20 & 00 & 20 & 20 & 20 \\
\hline & & $\mathrm{R}$ & 20 & 00 & 00 & 00 & 00 & 00 & 00 \\
\hline \multirow{3}{*}{ Bacillus cereus } & \multirow{3}{*}{5} & $\mathrm{~S}$ & 60 & 80 & 60 & 80 & 80 & 40 & 60 \\
\hline & & $\mathrm{I}$ & 40 & 20 & 40 & 20 & 20 & 40 & 20 \\
\hline & & $\mathrm{R}$ & 00 & 00 & 00 & 00 & 00 & 20 & 20 \\
\hline \multirow{3}{*}{ Escherichia coli } & \multirow{3}{*}{5} & $\mathrm{~S}$ & 40 & 40 & 60 & 60 & 20 & 20 & 20 \\
\hline & & $\mathrm{I}$ & 20 & 40 & 20 & 40 & 60 & 60 & 40 \\
\hline & & $\mathrm{R}$ & 40 & 20 & 20 & 00 & 20 & 20 & 40 \\
\hline \multirow{3}{*}{ Proteus mirabilis } & \multirow{3}{*}{5} & $\mathrm{~S}$ & 00 & 20 & 60 & 80 & 20 & 20 & 20 \\
\hline & & $\mathrm{I}$ & 40 & 60 & 20 & 20 & 40 & 40 & 60 \\
\hline & & $\mathrm{R}$ & 60 & 20 & 20 & 00 & 40 & 40 & 20 \\
\hline \multirow{3}{*}{ Pseudomonas spp. } & \multirow{3}{*}{5} & $\mathrm{~S}$ & 20 & 20 & 40 & 80 & 40 & 40 & 40 \\
\hline & & $\mathrm{I}$ & 20 & 20 & 40 & 20 & 40 & 20 & 40 \\
\hline & & $\mathrm{R}$ & 60 & 60 & 20 & 00 & 20 & 40 & 20 \\
\hline
\end{tabular}

Amoxicillin AX-30, Tetracycline TE-30, Enrofloxacin ENR-10, Florfenicol FFC-30, Lincomycin L-10, Cephalexin CL-30, Doxycycline D0-30 (Bioanalyse); $\mathrm{S}=$ sensitive, $\mathrm{I}=$ intermediate, $\mathrm{R}=$ resistance

the cloaca Gram-negative species such as E. coli and P. mirabilis and spore forming bacteria like Bacillus cereus predominate. Bacteria with major potential pathogenic such as Salmonella spp. were also isolated. Sensitivity assays showed that bacterias were very sensitive to enrofloxacin and florfenicol and had also low sensitivity to amoxicillin.

\section{REFERENCES}

1. Abulreesh H. H., R. Goulder, G. W. Scott (2007). Wild birds and human pathogens in the context of ringing and migration, Ringing and migration, 23:4, p. 193-200.

2. Botti V, Navillod FV, Domenis L, Orusa R, Pepe E, Robetto S, Guidetti C. (2013). Salmonella spp. and antibiotic-resistant strains in wild mammals and birds in northwestern Italy from 2002 to 2010. Veterinaria Italiana 49 (2), 195-202.

3. Clinical and Laboratory Standards Institute (2013). Performance Standards for Antimicrobial Disk and Dolution Susceptibility Test for Bacteria Isolated From Animals: Vet 01 - A4.

4. Dieter S. (2010). Păsările de interes cinegetic din România, Ed. Universității Transilvania, Brașov, p. 150-163, p. 291317.

5. Kiskova, J; Hrehova, Z; Janiga, M; Lukan, M; Haas, M; Cuvalova, Z Kiskova, J (2012). Bacterial prevalence in the Dunnock (Prunella modularis) in sub-alpine habitats of the Western Carpathians, Slovak Republic. ORNIS FENNICA, ; 89 (1): 34.

6. Markey B.K., F.C. Leonard, M. Archambault, A. Cullinane, D. Maguire. (2013). Clinical Veterinary Microbiology.
Elsevier, Edinburgh, London, New York, Oxford, Philadelphia, St Louis, Sydney, Toronto.

7. Mora, A., Ortega, N., Garcia, E., Viso, S., Candela, M.G., Dahbi, G., Cuello, F. and Caro, M.R. (2014) First Characterization of Escherichia coli Strains Isolated from Wildlife Griffon Vulture (Gyps fulvus) in the Southeast of Spain. Open Journal of Veterinary Medicine, 4, 329-333. http://dx.doi. org/10.4236/ojvm.2014.412040

8. Olinda R.G., M.C.A. Souza, J.N. Figueiredo, J.M.C. Silva, N.D. Alves, F.S.B. Bezerra, F.M.C. Feijó (2012). Diagnosis of Proteus spp. in Wild Birds Raised Under Captivity in Rio Grande Do Norte, Brazil. Arq. Inst. Biol., São Paulo, v.79, n.2, p.301-303.

9. Radhouani Hajer, Nuno Silva, PatríciaPoeta, CarmenTorres , Susana Correia and GilbertoIgrejas (2014). Potential impact of antimicrobial resistance in wild life, environment, and human health. Front.Microbiol. 5:23. doi:10.3389/fmicb.

10. Sarker M. A. H. , M. Jahan, M. N. Parvin, M. A. Malek and M. T. Hossain (2012). Identification of Bacterial Flora Isolated From Apparently Healthy Water Birds of Dhaka Zoo of Bangladesh. Bangl. J. Vet. Med. 10 (1\&2): 21-26.

11. Simonescu I. (1983). Fauna României, Ed. Albatros, București, p. 166-176.

12. Smith Shaun, Juan Wang, Séamus Fanning and Barry J McMahon (2014) Antimicrobial resistant bacteria in wild mammals and birds: a coincidence or cause for concern? Irish Veterinary Journal 67:8.

13. Soler Diego., Claudia Brieva, R. Wellman (2009) Mycobacteriosis in Wild Birds: The Potential risk of Disseminating a Little-known Infectious Disease, Facultad 
de Medicina Veterinaria y de Zootecnia, Universidad Nacional de Columbia, Rev. salud publica. 11(1): 134-144

14. Thomas, Nancy J., D. Bruce Hunter, and Carter T. Atkinson (2008). Infectious diseases of wild birds. John Wiley \& Sons,.

15. Tsiodras, S., Kelesidis, T., Kelesidis, I., Bauchinger, U., \&Falagas, M. E. (2008). Human infections associated with wild birds. Journal of Infection, 56(2), 83-98.
16. Vlahović Ksenija, Estella Prukner-Radovčić, Danijela Horvatek, Marina Pavlak, Tomislav Gomerčić, Zdravka Rumiha, and Alenka Dovč (2010). Bacterial and fungal flora in faecal samples from rooks (Corvus frugilegus) in the City of Zagreb, Croatia. Veterinarski Arhiv 80 (1), 8192, 